\title{
Article \\ Effect of Salicylic Acid in the Yield of Ricinine in Ricinus communis under Greenhouse Condition
}

\author{
Carlos Eduardo Zavala-Gómez ${ }^{1}$ D , Eloy Rodríguez-deLeón ${ }^{2} \mathbb{D}$, Mamadou Moustapha Bah ${ }^{2}$, Ana \\ Angélica Feregrino-Pérez ${ }^{1}$ D , Juan Campos-Guillén ${ }^{2}$, Aldo Amaro-Reyes ${ }^{2} \mathbb{D}$, José Alberto Rodríguez-Morales ${ }^{3}$, \\ Juan Fernando García-Trejo ${ }^{1}$, Antonio Flores-Macias ${ }^{4}\left(\mathbb{D}\right.$, Rodolfo Figueroa-Brito ${ }^{5}$ \\ and Miguel Angel Ramos-López ${ }^{2, *(D)}$
}

Citation: Zavala-Gómez, C.E.; Rodríguez-deLeón, E.; Bah, M.M.; Feregrino-Pérez, A.A.; CamposGuillén, J.; Amaro-Reyes, A.; Rodríguez-Morales, J.A.; García-Trejo, J.F.; Flores-Macias, A.; Figueroa-Brito, R.; et al. Effect of Salicylic Acid in the Yield of Ricinine in Ricinus communis under Greenhouse Condition. Plants 2021, 10, 1902. https://doi.org/ 10.3390/plants10091902

Academic Editor: Asunción Amorós

Received: 19 August 2021

Accepted: 10 September 2021

Published: 14 September 2021

Publisher's Note: MDPI stays neutral with regard to jurisdictional claims in published maps and institutional affiliations.

Copyright: (c) 2021 by the authors. Licensee MDPI, Basel, Switzerland. This article is an open access article distributed under the terms and conditions of the Creative Commons Attribution (CC BY) license (https:/ / creativecommons.org/licenses/by/ $4.0 /)$.
1 Biosystems Engineering Group, Division of Graduate Studies, Faculty of Engineering, Autonomous University of Queretaro, Cerro de las Campanas, S/N, Colonia Las Campanas, C.U., Santiago de Querétaro 76010, Mexico; ezavala2@gmail.com (C.E.Z.-G.); feregrino.angge@hotmail.com (A.A.F.-P.); fernando.garcia@uaq.mx (J.F.G.-T.)

2 Faculty of Chemistry, Autonomous University of Querétaro, Cerro de las Campanas, S/N, Colonia Las Campanas, Santiago de Querétaro 76010, Mexico; eloy.q22@gmail.com (E.R.-d.); moubahdia@yahoo.com.mx (M.M.B.); camposj78@hotmail.com (J.C.-G.); aldoamaro@gmail.com (A.A.-R.)

3 Nanosystems Laboratory, Division of Graduate Studies, Faculty of Engineering, Autonomous University of Querétaro, Cerro de las Campanas, S/N, Colonia Las Campanas, Santiago de Querétaro 76010, Mexico; josealberto970@hotmail.com

4 Department of Agricultural and Animal Production, Universidad Autónoma Metropolitana-Xochimilco, Calzada del Hueso 1100, Mexico City 04960, Mexico; aflores981@gmail.com

5 Biotic Products Development Center, National Polytechnic Institute, Calle Ceprobi No. 6, Yautepec 62731, Mexico; rfigueroa@ipn.mx

* Correspondence: agromyke@yahoo.com; Tel.: +52-44211921200 (ext. 5555)

\begin{abstract}
Castor bean (Ricinus communis) seeds contain ricinine, an alkaloid with insecticidal and insectistatic activities. Elicitation with salicylic acid (SA) has proven to stress $R$. communis and might modify the ricinine concentration. The aim of this study was to evaluate the concentration of ricinine in the bagasse of seeds from $R$. communis elicited with exogenous SA under greenhouse conditions. Plants were grown and divided into five groups, which were sprayed with SA and drench with $50 \mathrm{~mL} 60$ days after sowing with concentrations of SA $(0,100,300,600$ and $900 \mu \mathrm{M})$. Clusters were mixed and separated according to the treatment, and dried. The seeds were ground, the oil was extracted by Soxhlet with hexane, and then the bagasse was extracted with methanol. Ricinine was determined by HPLC. Elicitation did not change the plant height or diameter; the control group had $9.17 \mu \mathrm{g} \mathrm{mL} \mathrm{L}^{-1}$ of ricinine; and the concentrations followed a hormesis curve with the peak at $300 \mu \mathrm{M}$ of SA that had a ricinine concentration of $18.25 \mu \mathrm{g} \mathrm{mL}^{-1}$. Elicitation with SA might be a cost-effective technique to increase ricinine from $R$. communis bagasse.
\end{abstract}

Keywords: Ricinus communis; elicitation; ricinine

\section{Introduction}

Castor bean plant Ricinus communis is a nonedible seed crop. This species is native of tropical Africa, and due to its commercial importance, is currently cultivated worldwide in countries with tropical weather such as Mexico [1]. This plant contains metabolites that include proteins, carbohydrates, minerals, albumins, ricinoleic acid, ricin, ricinine, N-demethylricinine, kaempferol-3-0- $\beta$-D-xyylopyranoside, kaempferol-3-0- $\beta$-Dglucopyranoside, quercetin-3-0- $\beta$-D-xylopyranoside, quercetin-3-0- $\beta$-D-glucopyranoside, kaempferol-3-0- $\beta$-rutinoside, and quercetin-3-0- $\beta$-rutinoside, which makes the plant functional in more than 700 industrial applications such as the production of cosmetics, paints, biofuels and pesticides [2-5].

Ricinine is one of the most important metabolites of $R$. communis: it is an alkaloid (3-Cyano-4 methoxy-N-methyl-2-pyridone), which belongs to the group of piperidine 
alkaloids, and depending on the concentration, it could cause emesis, nausea, and even death if ingested [6]. This alkaloid contains a cyano group in its structure, which gives its toxicity; a property that suggests its use as an insecticidal, against Atta sexdenx rubropilosa and against Spodoptera frugiperda $[7,8]$. It exhibits antimicrobial activity against the bacterial species Staphylococcus aureus, Escherichia coli, Klebsiella pneumoniae, Pseudomonas aeruginosa, and the fungal species Candida albicans [9]. Ricinine is present in all parts of the plant, and its production can be enhanced by nitrogen, and environmental factors such as salinity and drought [10].

An additional method to enhance the production of secondary metabolites such as alkaloids is by elicitation [11], which is the induction of the immune system of a plant by an external agent [12]. For example, Akhgari et al. [13] increased the concentration of terpenoid indole alkaloid with methyl jasmonate. Taha and Twaij [14] demonstrated an increase in phenolic compounds eliciting $R$. communis with $\mathrm{AgNO}_{3}$. Another common compound used in elicitation is salicylic acid (SA), which is a phenolic compound and a natural constituent of many plant species [15]; it is involved in responses to different types of stress (biotic and abiotic) and defense against pathogen attacks [16]. SA affects the oxide/reduction balance of plant cells, and induces adaptive, physiological, and morphological responses [17]. It is considered as a bioregulator of growth and has been shown to increase the production of foliar biomass in plants, roots, and fruits [18]. SA has been shown to enhance the production of alkaloids in different plant models [19].

There is no evidence of the effect of SA on the secondary metabolites of $R$. communis. However, it has been shown to increase the concentration of phenolic, flavonoid, and flavonol compounds in Helianthus annuus [20]; improve the yields of alkaloids and flavonoids in Isatis tinctoria [21]; and improve the production of benzylisoquinoline alkaloids in Papaver armeniacum [22].

Given the industrial importance of $R$. communis and the high availability around the world, the aim of this study was to evaluate salicylic acid in the yield of ricinine alkaloid contained in $R$. communis seeds under greenhouse conditions.

\section{Results}

\subsection{Plant Measurement and Oil Content of R. communis}

The height of the plants ranged from $51.05 \mathrm{~cm}$ to $58.31 \mathrm{~cm}$ at day 7, and $195.68 \mathrm{~cm}$ to $216.27 \mathrm{~cm}$ at day 40; the stem diameter ranged from $4.09 \mathrm{~cm}$ to $4.89 \mathrm{~cm}$ at day 7 , and $8.65 \mathrm{~cm}$ to $9.19 \mathrm{~cm}$ at day 40 . No statistical differences were found in the heights and diameters between the treatments (Table 1). This showed homogeneity in the growth of all plants of this study, before applying the elicitor (SA) at day 40.

Table 1. Height of stem diameters of $R$. communis plants before treatment with salicylic acid at days 7 and 40 after sowing.

\begin{tabular}{ccccc}
\hline Treatment & $\begin{array}{c}\text { Height at 7 } \\
\text { Days } \mathbf{( c m )}\end{array}$ & $\begin{array}{c}\text { Height at } \\
\text { 40 Days } \mathbf{( c m )}\end{array}$ & $\begin{array}{c}\text { Stem Diameter } \\
\text { at 7 Days } \mathbf{( c m )}\end{array}$ & $\begin{array}{c}\text { Stem Diameter } \\
\text { at 40 Days (cm) }\end{array}$ \\
\hline $900 \mu \mathrm{M}$ & $58.21 \pm 16.06 \mathrm{a}$ & $195.68 \pm 26.92 \mathrm{a}$ & $4.36 \pm 0.81 \mathrm{a}$ & $8.84 \pm 0.76 \mathrm{a}$ \\
$600 \mu \mathrm{M}$ & $51.05 \pm 11.15 \mathrm{a}$ & $216.27 \pm 16.77 \mathrm{a}$ & $4.09 \pm 0.65 \mathrm{a}$ & $8.83 \pm 0.33 \mathrm{a}$ \\
$300 \mu \mathrm{M}$ & $5700 \pm 9.44 \mathrm{a}$ & $210.64 \pm 27.09 \mathrm{a}$ & $4.42 \pm 0.95 \mathrm{a}$ & $9.11 \pm 0.82 \mathrm{a}$ \\
$100 \mu \mathrm{M}$ & $54.70 \pm 8.38 \mathrm{a}$ & $209.39 \pm 23.22 \mathrm{a}$ & $4.63 \pm 0.71 \mathrm{a}$ & $9.19 \pm 0.88 \mathrm{a}$ \\
$0 \mu \mathrm{M}$ & $58.31 \pm 13.80 \mathrm{a}$ & $207.38 \pm 26.58 \mathrm{a}$ & $4.89 \pm 0.51 \mathrm{a}$ & $8.65 \pm 0.71 \mathrm{a}$ \\
\hline
\end{tabular}

The results are the average of 60 plants \pm standard deviation. Different letters indicate the statistical difference Tukey test, $p=0.05$.

The oil content ranged from $34.89 \%$ to $50.23 \%$ between the treatments. Increments of $14 \%$ and $7.5 \%$ with respect to the control $(0 \mu \mathrm{M})$ with the treatments of $900 \mu \mathrm{M}$ and $600 \mu \mathrm{M}$ were observed. The weight of 100 seeds increased $25.7 \%$ in the $900 \mu \mathrm{M}$ treatment and $13.6 \%$ in the $600 \mu \mathrm{M}$ treatment as compared with the control. The treatment of $100 \mu \mathrm{M}$ decreased by $8.5 \%$; however, this change was not statistically significant. There were no statistical 
differences between the treatments in the length (from $14.30 \mathrm{~mm}$ to $14.39 \mathrm{~mm}$ ), width (from $9.03 \mathrm{~mm}$ to $9.10 \mathrm{~mm}$ ) and thickness (from $6.60 \mathrm{~mm}$ to 6.66 ) of the seeds (Table 2).

Table 2. Oil content, weight of 100 seeds and morphological characteristics of castor seeds of plants treated with salicylic acid.

\begin{tabular}{cccccc}
\hline Trat & Oil Content (\%) & Weight of 100 Seeds (g) & Seed Length (mm) & Seed Width (mm) & Seed Thickness (mm) \\
\hline $900 \mu \mathrm{M}$ & $50.23 \pm 1.55 \mathrm{a}$ & $24.70 \pm 2.89 \mathrm{a}$ & $14.37 \pm 0.13 \mathrm{a}$ & $9.10 \pm 0.09 \mathrm{a}$ & $6.66 \pm 0.06 \mathrm{a}$ \\
$600 \mu \mathrm{M}$ & $43.75 \pm 2.36 \mathrm{~b}$ & $22.33 \pm 3.12 \mathrm{ab}$ & $14.23 \pm 0.12 \mathrm{a}$ & $9.03 \pm 0.14 \mathrm{a}$ & $6.64 \pm 0.07 \mathrm{a}$ \\
$300 \mu \mathrm{M}$ & $38.11 \pm 0.78 \mathrm{c}$ & $21.50 \pm 1.15 \mathrm{bc}$ & $14.37 \pm 0.12 \mathrm{a}$ & $9.08 \pm 0.10 \mathrm{a}$ & $6.64 \pm 0.06 \mathrm{a}$ \\
$100 \mu \mathrm{M}$ & $34.89 \pm 5.98 \mathrm{c}$ & $17.97 \pm 1.58 \mathrm{~d}$ & $14.30 \pm 0.10 \mathrm{a}$ & $9.10 \pm 0.06 \mathrm{a}$ & $6.60 \pm 0.06 \mathrm{a}$ \\
$0 \mu \mathrm{M}$ & $36.23 \pm 4.17 \mathrm{c}$ & $19.65 \pm 2.10 \mathrm{~cd}$ & $14.39 \pm 0.30 \mathrm{a}$ & $9.07 \pm 0.08 \mathrm{a}$ & $6.65 \pm 0.11 \mathrm{a}$ \\
\hline
\end{tabular}

Trat $=$ Treatment. The data of oil content are the average of 3 measurements. Seed length, width, and thickness are the average of the measure of 100 seeds. Different letters indicate the statistical difference Tukey test, $p=0.05$.

\subsection{Ricinine Standard Calibration Curve}

Figure 1 shows the HPLC chromatogram of the ricinine standard and its absorption spectrum in UV-Vis. The retention time of the different concentrations of ricinine standard ranged between $8.797 \mathrm{~min}$ and $8.814 \mathrm{~min}$ The areas under the curve ranged between 425,421 for the $6 \mu \mathrm{g} \mathrm{mL}^{-1}$ and 1,930,221 for the $20 \mu \mathrm{g} \mathrm{mL}{ }^{-1}$ samples (Table 3). A high linearity of $\mathrm{R}^{2}=0.9618$ was reached, which allowed it to be used for the quantification of ricinine extracts (Figure 2). The detection and quantification limits for the calibration curve were $3.2 \mu \mathrm{g} \mathrm{mL}^{-1}$ and $5.3 \mu \mathrm{g} \mathrm{mL}^{-1}$, respectively.

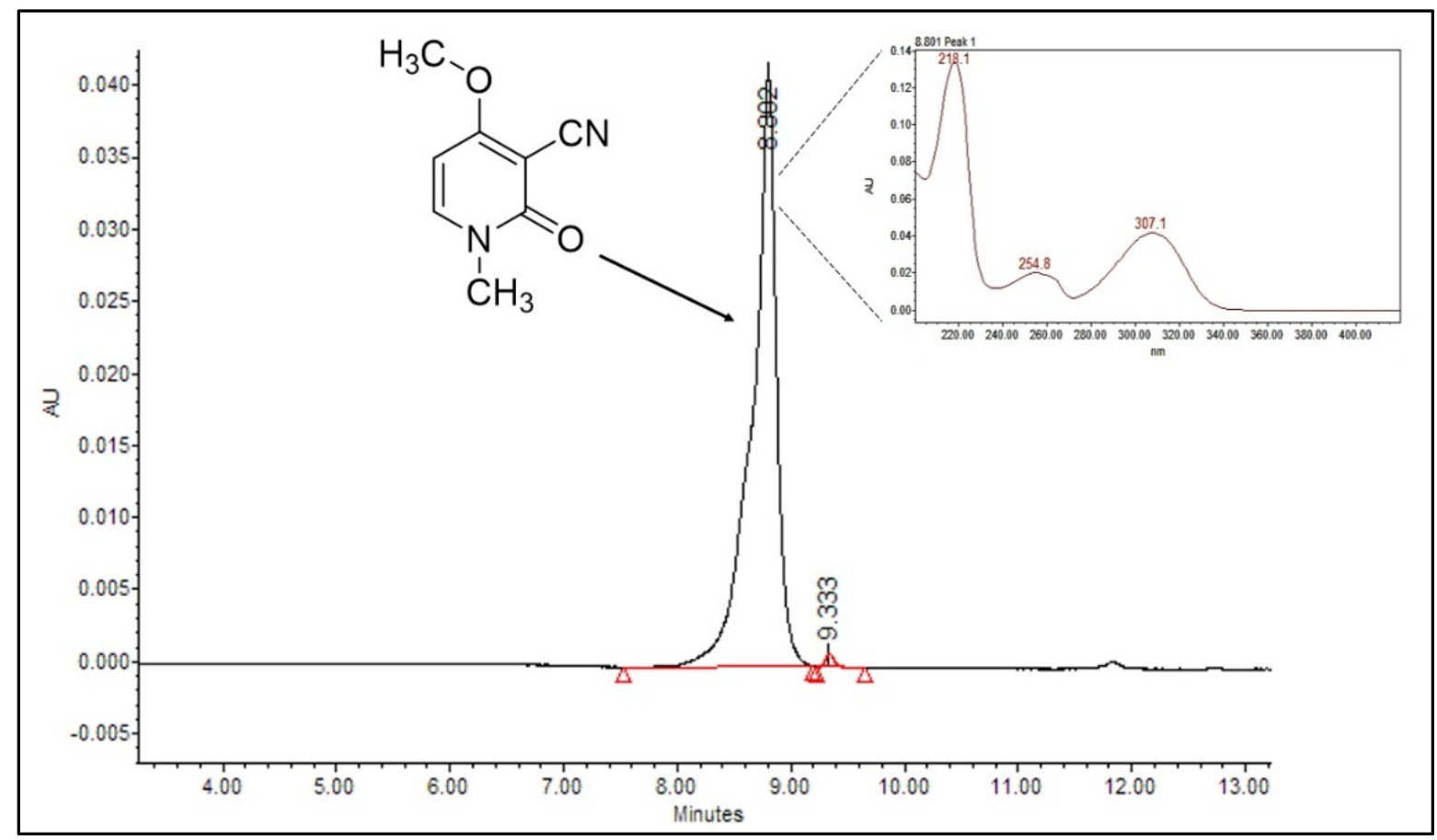

Figure 1. Chromatogram of ricinine standard and its absorption spectrum in UV-Vis.

Table 3. Ricinine concentration and area under the curve of ricinine standard.

\begin{tabular}{ccc}
\hline [ $\mu \mathrm{g} \mathrm{mL}^{-\mathbf{1}}$ ] & Retention Time (minutes) & Area under the Curve \\
\hline 20 & 8.814 & $1,930,221$ \\
16 & 8.804 & $1,177,116$ \\
8 & 8.797 & 608,784 \\
6 & 8.802 & 425,421 \\
0 & 0 & 0 \\
\hline
\end{tabular}




\section{Ricinine calibration curve}

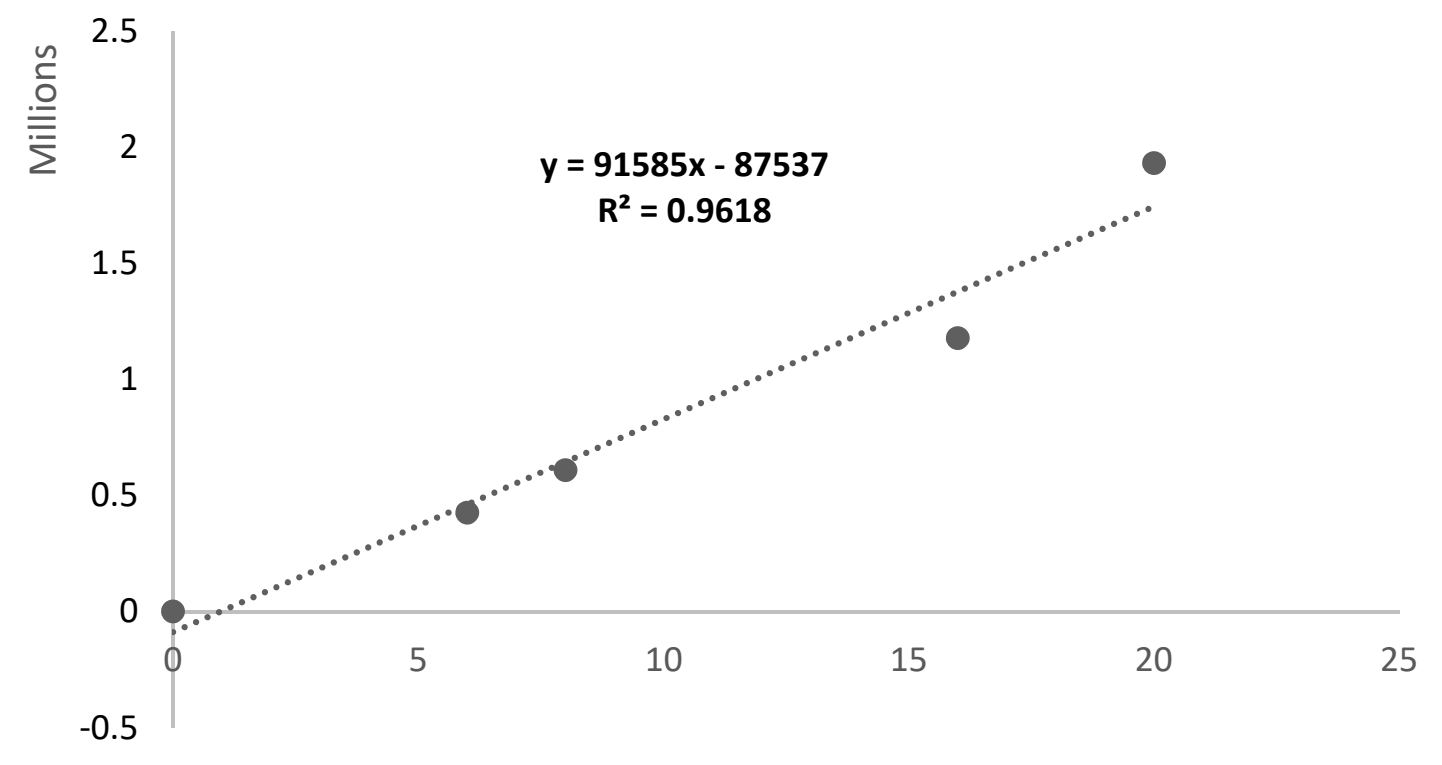

Figure 2. Ricinine calibration curve.

\subsection{Ricinine Quantification of Methanolic Extract}

All samples presented ricinine concentrations between $0.92 \mathrm{mg} \mathrm{g}^{-1}(0 \mu \mathrm{M})$ and 1.58 at $\mathrm{mg} \mathrm{g}^{-1}(600 \mu \mathrm{M})$ of extract (Table 4$)$, which is exhibited as a hormesis curve for this alkaloid using salicylic acid. The peak of this curve was at $300 \mu \mathrm{M}$ of SA and then decreased as the concentration of SA increased, as seen in Figure 3. The chromatogram of $300 \mu \mathrm{M}$ of SA is observed in Figure 4.

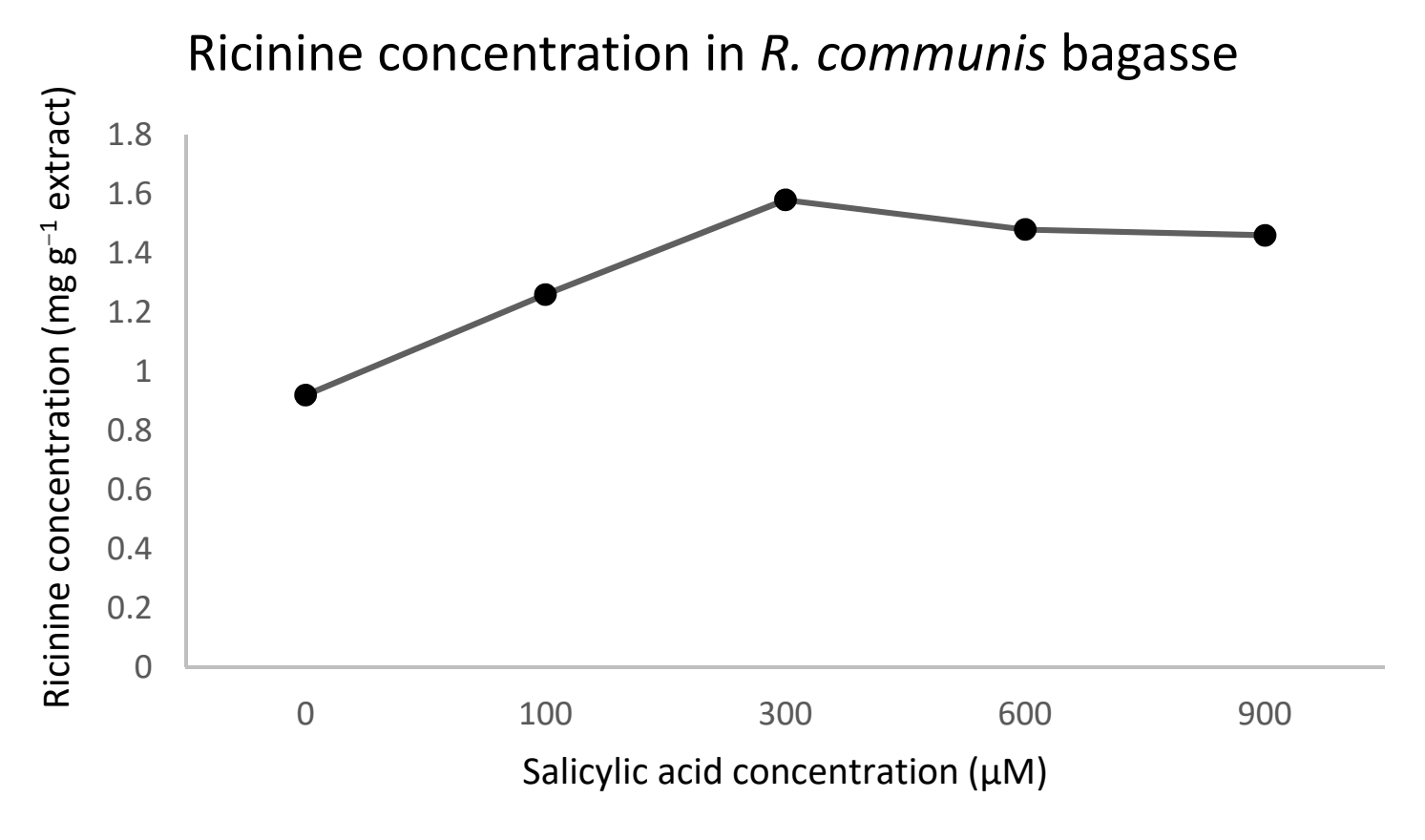

Figure 3. Comparison of ricinine in $R$. communis samples treated with different concentrations of SA. 
Table 4. Ricinine concentration and area under the curve of the methanolic extracts of $R$. communis plants treated with salicylic acid.

\begin{tabular}{ccccccc}
\hline Trat & $\begin{array}{c}\text { Weight Sample } \\
(\mathbf{m g})\end{array}$ & $\begin{array}{c}\text { Final Volume } \\
(\mathbf{m L})\end{array}$ & $\begin{array}{c}\text { Area under the } \\
\text { Curve }\end{array}$ & $\begin{array}{c}\text { Retention } \\
\text { Time (minutes) }\end{array}$ & $\begin{array}{c}\text { Concentration } \\
\left(\boldsymbol{\mu} \mathbf{g} \mathbf{~ m L}^{-\mathbf{1}}\right)\end{array}$ & $\begin{array}{c}\text { Concentration } \\
\left(\mathbf{m g} \mathbf{g}^{-\mathbf{1}} \mathbf{E x t r a c t}^{\mathbf{n}}\right)\end{array}$ \\
\hline $900 \mu \mathrm{M}$ & 11.5 & 1 & $1,449,959$ & 8.790 & 16.78 & $1.46 \pm 0.08$ \\
$600 \mu \mathrm{M}$ & 10.2 & 1 & $1,301,895$ & 8.739 & 15.17 & $1.48 \pm 0.05$ \\
$300 \mu \mathrm{M}$ & 11.5 & 1 & $1,584,532$ & 8.823 & 18.25 & $1.58 \pm 0.07$ \\
$100 \mu \mathrm{M}$ & 10.2 & 1 & $1,091,388$ & 8.868 & 12.87 & $1.26 \pm 0.06$ \\
$0 \mu \mathrm{M}$ & 10.0 & 1 & 752,871 & 8.926 & 9.17 & $0.92 \pm 0.05$ \\
\hline
\end{tabular}

The data of concentration is the average of 3 measures \pm standard deviation.

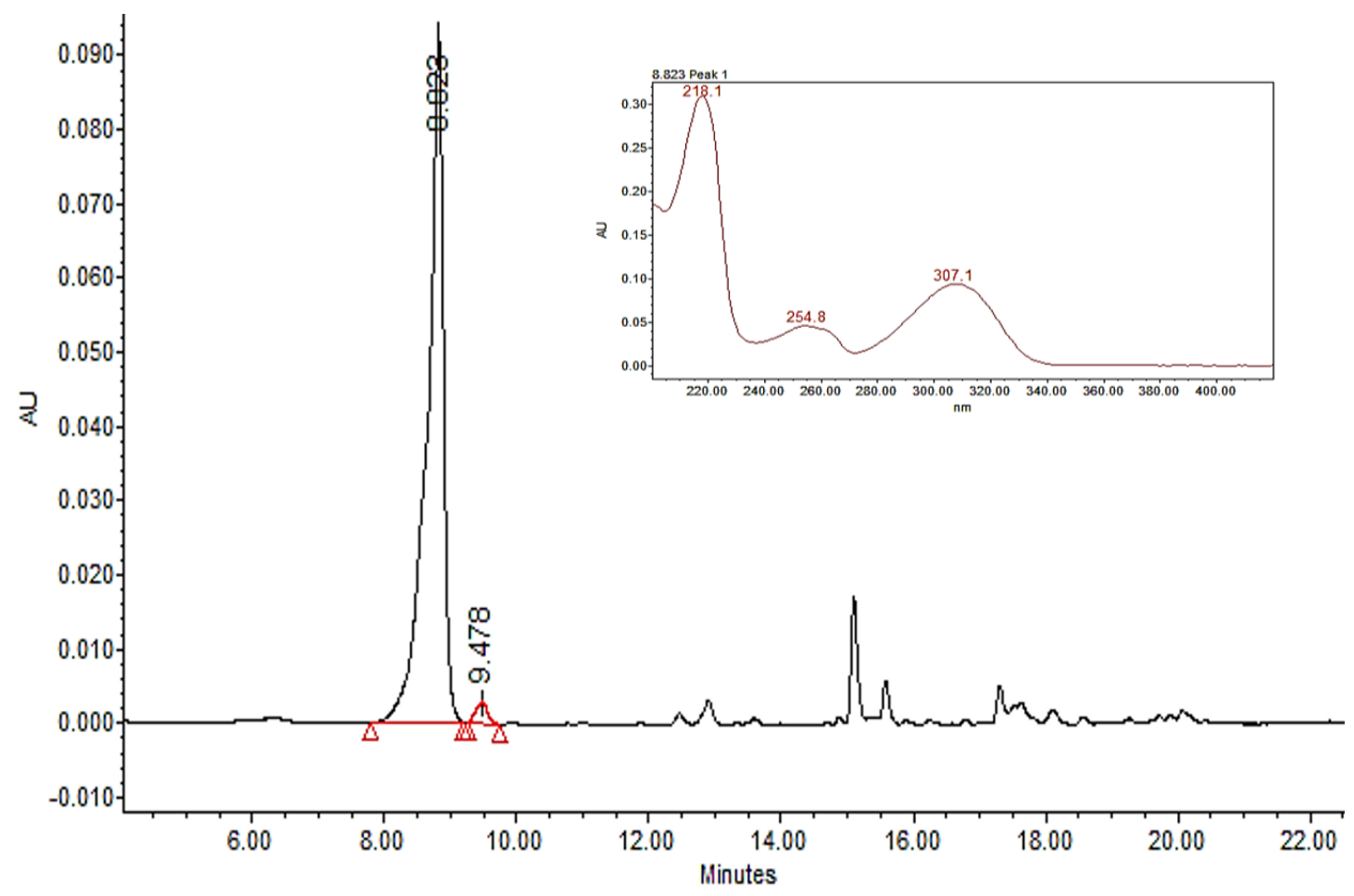

Figure 4. HPLC chromatogram of the sample elicited with $300 \mu \mathrm{M}$. salicylic acid.

\section{Discussion}

\subsection{Importance and Novelty of the Research}

In this study, we demonstrated the effectiveness of SA as an elicitor to increase ricinine yield in $R$. communis for the first time. The highest yield was at a concentration of $300 \mu \mathrm{M}$ of SA.

\subsection{Difference in Height and Diameter}

In contrast to our results, other studies testing the effectiveness of SA as an elicitor found various results: Hasanuzzaman et al. [23] observed an increase of $15 \%$ over the control in the height of Brassica campestris plants grown in lead-amended soils $(1.0 \mathrm{mM})$ and elicited with salicylic acid $(0.25 \mathrm{mM}) 30$ days after sowing. However, after 45 days and at harvest, there were decreases of $35 \%$ and $26 \%$ in the heights of the plants, with respect to the control. Zamaninejad et al. [24] in Zea mays elicited with SA (1 $\mathrm{mM})$ performed before flowering demonstrated an increase of $15 \%$ in the height and $5 \%$ stem diameter, with respect to the control. In addition, Tucuch-Haas et al. [25] in Zea mays treated with SA $(1 \mu \mathrm{M})$ measured 140 days after sowing had an increase of $14 \%$ in the height and $41 \%$ of the stem diameter, with respect to the control. 
As can be seen in these studies, salicylic acid increased the height and stem diameter of the plants elicited with SA. However, in this work, no difference was found in height and stem diameter because it was not intended to increase these variables. In addition, the measurements of the plants were taken before elicitation. This study aimed to test the increase in the secondary metabolite, ricinine.

\subsection{Effectiveness of $S A$ as an Elicitor or Secondary Metabolites}

Similar to our findings, a broad number of studies have found elicitation to be effective to increase the yield of secondary metabolites. For instance, Estaji and Niknam [26] found that Silybum marianum elicited with SA (1 Mm) had an increased seed oil content of 7\%, as compared to the control. Safeer et al. [27] reported an increase of $14 \%$ in the seed oil content of Helianthus annuus elicited with SA $(100 \mathrm{mM})$, with respect to the control. However, there are also studies showing conflicting evidence: Ullah and Bano [28] showed a 6\% decrease in the seed oil content in Carthamus tinctorius elicited with SA $(1 \mu \mathrm{M})$ with respect to the control. In this research, it was shown that the seed oil content increased by $14 \%$ with respect to the control after eliciting $R$. communis with SA $(900 \mu \mathrm{M})$.

For the measurements of the morphology of the seeds (length, width, and thickness) there was no significant difference between treatments. However, for the weight of 100 seeds, concentrations $600 \mu \mathrm{M}$ and $900 \mu \mathrm{M}$ had $25 \%$ and $14 \%$ higher weights with respect to the control, respectively; this was also reflected in the oil content.

Flores-Macías et al. [29] obtained a linearity of the calibration curve of ricinine standard of $\mathrm{R}^{2}=0.992$ by HPLC, which exhibited a high correlation with different ricinine standard concentrations $\left(2.0,0.2,0.02,0.002\right.$, and $\left.0 \mathrm{mg} \mathrm{mL}^{-1}\right)$. In another investigation, Wang et al. [30] reported $\mathrm{R}^{2}$ values of 0.9992 and 0.9988 with HPLC and LC-MS, of the standard solution of ricinine with different standard concentrations $(27.7,13.8,6.92,3.46$, $1.73,0.87,0.43,0.22,0.11,0.05$, and $\left.0 \mu \mathrm{g} \mathrm{mL}^{-1}\right)$ and $(500,250,125,62.5,31.2,15.6,7.8,3.9$, 1.8 and $0 \mathrm{ng} \mathrm{mL}^{-1}$ ), respectively. Isenberg et al. [31] determined the correlation of ricinine standard by HPLC, which showed a high linearity of $\mathrm{R}^{2}=0.996$ with different ricinine standard concentrations $\left(200,20.0,0.800\right.$, and $\left.0 \mathrm{ng} \mathrm{mL}^{-1}\right)$. In this research, a linearity of $\mathrm{R}^{2}=0.9618$ was obtained with different ricinine standard concentrations $(0,6,8,16$, $20 \mu \mathrm{g} \mathrm{L}^{-1}$ ); we proceeded to quantify the ricinine in the extracts.

The ricinine concentrations in the control group were similar to those reported by Nebo et al. [32] (1.3921 to $1.442 \mathrm{mg} \mathrm{g}^{-1}$ ) in leaves of the methanolic extract of $R$. communis. On the other hand, Flores-Macías et al. [29] found concentrations in the methanolic extracts of areal parts of $R$. commuis $\left(894,101,103\right.$ and $\left.104.2 \mu \mathrm{g} \mathrm{mL}^{-1}\right)$. In this work, the concentrations of the methanolic extracts were similar to those reported by Nebo et al. [32], where the concentrations ranged from 0.92 to $1.58 \mathrm{mg} \mathrm{g}^{-1}$. However, the values for the concentrations in this study were lower than those reported by Flores-Macías et al. [29], which were between 9.17 and $18.25 \mu \mathrm{g} \mathrm{mL}^{-1}$.

\subsection{Implications}

Giving the high availability of wild R. communis in Mexico and other tropical countries and its insecticidal activity against species such as $S$. frugiperda and A. aegypti, it has been considered and used in insecticides $[8,33,34]$.

These results might have implications in the commercial production of ricinine, and in the production of secondary metabolites from $R$. communis. [35]. Ricinine is an integrated pest management control alternative of biological origin that provides novel modes of action and reduces the risk of cross-resistance [36]. The use of botanical insecticides is an accessible and low-cost control alternative for farmers [37]. Furthermore, obtaining active extracts does not require complex methodologies [38]; for instance, the extracts prepared in this study were of the methanolic type and their preparation was carried out simply and quickly with the help of an ultrasonic bath. This technique has also been used and described in similar studies $[39,40]$. Another benefit of using biological insecticides such as ricinine is that it has specific targets; thus, it does not affect endemic fauna [41]. 
The ricinine extracts of this study were obtained from the bagasse resulting from the extraction of the oil, which otherwise would have been considered as toxic waste. In addition, hydrolysis of the bagasse has shown to decrease its toxicity, providing additional benefits [42].

\section{Materials and Methods}

\subsection{Field Conditions}

The study was carried out in a $432 \mathrm{~m}^{2}$ greenhouse at the Engineering Faculty of the Autonomous University of Querétaro Amazcala Campus in El Marques, Querétaro, Mexico (DMS latitude: $20^{\circ} 42^{\prime} 18.576^{\prime \prime} \mathrm{N}$, longitude: $100^{\circ} 15^{\prime} 57.24^{\prime \prime} \mathrm{W}$ ), during the seasons of autumn and winter, 2019. Weather conditions during the study were an average temperature of $27.8^{\circ} \mathrm{C}$, photoperiod of $14 \mathrm{~h}$ light $/ 10 \mathrm{~h}$ dark, and relative humidity of $43 \%$.

The greenhouse was divided randomly into 4 blocks, with 3 repetitions, 5 plants per experimental unit and 4 treatments of SA as an elicitor and a control distilled water.

\subsection{Plant Materials}

The seeds of the Guanajuatoil variety of $R$. communis were provided by Dr. Miguel Hernández Martínez from the National Institute of Forestry Agricultural and Livestock Research Center (INIFAP) Experimental field Celaya.

The greenhouse was cleaned and all weeds were removed. Sowing and fertilization were carried out according to the methodology proposed by Hernández Martínez and Montes Hernández [43]: 600 seeds (2 per hole) were sown, at a depth of $30 \mathrm{~cm}$, with a distance of $0.7 \mathrm{~m}$ between each other, across 10 cultivation lines with a separation of $1 \mathrm{~m}$ between lines. Sowing was carried out on 24 July 2019. Fertilization was performed by fertigation with doses of 60-40-00 NPK, with applications of 30-40-00 on the sowing day and a second application of 30-00-00 35 days after germination. Irrigation was carried out by means of a half drip every third day for a period of $30 \mathrm{~min}$. Each group of plants was elicited with different concentrations of salicylic acid (100, 300,600 and $900 \mu \mathrm{M}) 60$ days after sowing (21 September 2019) by foliar application, and by drench using a fumigation tank. The control plants received the same treatment with distilled water.

The clusters were harvested and sun-dried for 2 weeks, and then placed in a solar dryer for one more week. Finally, the seeds were extracted from the clusters.

\subsection{Plant and Seed Measurements}

The stem diameters and heights of the plants were measured at 7 and 40 days after sowing with a measuring tape (Truper H-1766, Jilotepec, State of México, Mexico). The stem diameter was measured at ground level and the height was measured from ground level to the highest point of the plant. After harvesting with a vernier (Steren, Azcapotzalco, Mexico City, Mexico), a random sample of 100 seeds was collected [44], and the weight, seed length, seed width and seed thickness were measured.

\subsection{Oil Extraction}

The oil was extracted by taking a composite sample of $30 \mathrm{~g}$ seeds per treatment and block, from which they were taken and weighed on an analytical balance (Ohaus PA323C, Melrose, MA, USA) Afterwards, they were ground and inserted into a Soxhlet extractor connected to a $500 \mathrm{~mL}$ flask containing $250 \mathrm{~mL}$ of $\mathrm{n}$-hexane. The extraction was conducted at $55{ }^{\circ} \mathrm{C}$, the boiling temperature of technical-grade n-hexane (Sigma-Aldrich, Toluca, State of México, México). During the extraction, an ice bath was used to control the temperature. After the extraction, the samples were centrifuged and separated into layers to remove the solvent with a rotary evaporator: IKA RV 10 basic (Staufen im Breisgau, BW, Germany).

\subsection{Sample Preparation}

The methanolic extract of $R$. communis was obtained from the bagasse of the seeds after the oil extraction: $10 \mathrm{~g}$ of bagasse was placed into a $250 \mathrm{~mL}$ Erlenmeyer flask with 
$100 \mathrm{~mL}$ of reagent-grade methanol (Sigma-Aldrich, Toluca, State of Mexico, Mexico). The mixture was placed into ultrasonic bath [Elmasonic S $40(\mathrm{H})$ (Singen, BW, Germany)] for one hour at $50{ }^{\circ} \mathrm{C}$. Then, the extract was filtered by gravity into a funnel with a Whatman No 3 filter (Schenectady, NY, USA). Finally, the solvent was eliminated by using a IKA RV 10 basic (Staufen im Breisgau, BW, Germany) rotary evaporator.

\subsection{Ricinine Quantification in R. communis Bagasse}

HPLC analyses were performed using Waters equipment (Milford, MA, USA), A1liance model, composed of a quaternary pump model e2695 multi-solvent delivery system and a 2998 Diode Array Detector (DAD), using a $C_{18}$ column Agilent Zorbax (5 $\mu$, $150 \times 4.5 \mathrm{~mm})($ Santa Clara, CA, USA). The mobile phase was composed of aqueous acetic acid $0.0125 \mathrm{~N}$ and acetonitrile $\left(\mathrm{CH}_{3} \mathrm{CN}\right)$ in a linear gradient (as shown in Table 5) at a flow rate of $1.0 \mathrm{~mL} \mathrm{~min}^{-1}$. The run time was of $25 \mathrm{~min}$, the volume of the injection was $20 \mu \mathrm{L}$ and the ricinine was detected at $310 \mathrm{~nm}$. Data acquisition and processing of chromatographic information were performed by Empower 3 Software (Milford, MA, USA).

Table 5. Elution gradient for ricinine analysis.

\begin{tabular}{ccc}
\hline Time (minutes) & Acetic Acid Solution $\mathbf{0 . 0 1 2 5 N}$ & Acetonitrile \\
\hline 0 & $95 \%$ & $5 \%$ \\
2 & $95 \%$ & $5 \%$ \\
5 & $85 \%$ & $15 \%$ \\
20 & $50 \%$ & $50 \%$ \\
25 & $95 \%$ & $5 \%$ \\
\hline
\end{tabular}

For the quantification of ricinine, the calibration curve was obtained using the following concentrations $\left(\mu \mathrm{g} \mathrm{mL} \mathrm{mL}^{-1}\right): 0,6,8,16$, and 20 . The areas under the curves (y) obtained for each standard were plotted versus the concentrations used $(\mathrm{x})$, and a linear correlation was established as $y=m x+b$. The amounts of ricinine were calculated by interpolation in the calibration curve. The detection limit and quantification limit were determined by the least-squares method.

\subsection{Statistical Analysis}

Descriptive analyses of the main characteristics of the plants treated with different concentrations of SA were performed. Analysis of covariance (ANCOVA) with a post hoc Tukey test were performed to assess differences between the treatments. Statistical significance was set at $(p<0.05)$.

\section{Conclusions}

In this research, it was found that the combination of the elicitation techniques of foliar application and drench with SA was found to improve effectively ricinine concentrations in $R$. communis plant seeds. Additionally, the hormesis point of salicylic acid was found at $300 \mu \mathrm{M}$ to increase the concentration of this alkaloid, and start decreasing at $600 \mu \mathrm{M}$ and having the point of least concentration at $900 \mu \mathrm{M}$. Given the industrial importance of ricinine, SA might be a cost-effective solution to increase its yield in $R$. communis seeds.

Author Contributions: C.E.Z.-G. and M.A.R.-L. conceived the experiment and wrote part of the manuscript; E.R.-d. and M.M.B. conducted the HPLC experiments and collected the data; A.A.F.-P. and J.A.R.-M. performed the plant measurements and statistical analysis; J.C.-G. and A.A.-R. designed the experiment and performed the chemical analyses; J.F.G.-T. conducted the oil extraction; A.F.-M. and R.F.-B. reviewed and edited the manuscript; M.A.R.-L. performed the statistical analysis and wrote part of the manuscript. All authors have read and agreed to the published version of the manuscript.

Funding: This research received no external funding.

Institutional Review Board Statement: Not applicable. 
Informed Consent Statement: Not applicable.

Data Availability Statement: Not applicable.

Acknowledgments: We would like to thank the National Council of Science and Technology, México (CONACYT) for the grant number714272.

Conflicts of Interest: The authors declare no conflict of interest.

\section{References}

1. Mondal, B.; Das, S.K. Comparative evaluation of mahua (Bassia latifolia) oil cake and castor bean (Ricinus communis) seed as fish toxicants for tilapia (Oreochromis mossambicus) and panchax (Aplocheilus panchax) with residual toxicity assessment on Labeo bata. Aquac. Res. 2019, 50, 2341-2349. [CrossRef]

2. Kang, S.S.; Cordell, G.A.; Soejarto, D.D.; Fong, H.H. Alkaloids and flavonoids from Ricinus communis. J. Nat. Prod. 1985, 48, 155-156. [CrossRef]

3. Chakrabarty, S.; Islam, A.K.M.A.; Yaakob, Z.; Islam, A.K.M.M. Castor (Ricinus communis): An Underutilized Oil Crop in the South East Asia. In Agroecosystems_-Very Complex Environmental Systems; IntechOpen: London, UK, 2021; p. 61.

4. Arboleda, F.J.; Guzmán, Ó.A.; Mejía, L.F. Efecto de Extractos Cetónicos de Higuerilla (Ricinus communis Linneo.) Sobre el Nematodo Barrenador [Radopholus similis (cobb.) Thorne] en Condiciones In Vitro. Luna Azul 2012, 35, $28-47$.

5. Ali, B. Salicylic Acid: An Efficient Elicitor of Secondary Metabolite Production in Plants. Biocatal. Agric. Biotechnol. 2021, 31, 101884. [CrossRef]

6. Zhu, Q.-L.; Gu, H.; Ke, Z. Congeneration Biodiesel, Ricinine and Nontoxic Meal from Castor Seed. Renew. Energy 2018, 120, 51-59. [CrossRef]

7. Bigi, M.F.M.; Torkomian, V.L.; De Groote, S.T.; Hebling, M.J.A.; Bueno, O.C.; Pagnocca, F.C.; Da Silva, M.F.G. Activity of Ricinus communis (Euphorbiaceae) and ricinine against the leaf-cutting ant Atta sexdens rubropilosa (Hymenoptera: Formicidae) and the symbiotic fungus Leucoagaricus gongylophorus. Pest Manag. Sci. 2004, 60, 933-938. [CrossRef] [PubMed]

8. Ramos-López, M.A.; Pérez, S. Activity of Ricinus communis (Euphorbiaceae) against Spodoptera frugiperda (Lepidoptera: Noctuidae). Afr. J. Biotechnol. 2010, 9, 1359-1365. [CrossRef]

9. Santos, P.M.; Batista, D.L.J.; Ribeiro, L.A.F.; Boffo, E.F.; de Cerqueira, M.D.; Martins, D.; de Castro, R.D.; de Souza-Neta, L.C.; Pinto, E.; Zambotti-Villela, L.; et al. Identification of Antioxidant and Antimicrobial Compounds from the Oilseed Crop Ricinus communis Using a Multiplatform Metabolite Profiling Approach. Ind. Crops Prod. 2018, 124, 834-844. [CrossRef]

10. El-Naggar, M.H.; Elgaml, A.; Abdel Bar, F.M.; Badria, F.A. Antimicrobial and Antiquorum-Sensing Activity of Ricinus communis Extracts and Ricinine Derivatives. Nat. Prod. Res. 2019, 33, 1556-1562. [CrossRef]

11. Severino, L.S.; Auld, D.L.; Baldanzi, M.; Cândido, M.J.D.; Chen, G.; Crosby, W.; Tan, D.; He, X.; Lakshmamma, P.; Lavanya, C.; et al. A Review on the Challenges for Increased Production of Castor. Agron. J. 2012, 104, 853-880. [CrossRef]

12. Narayani, M.; Srivastava, S. Elicitation: A Stimulation of Stress in in Vitro Plant Cell/tissue Cultures for Enhancement of Secondary Metabolite Production. Phytochem. Rev. 2017, 16, 1227-1252. [CrossRef]

13. Luciano, A.-J.; Irineo, T.-P.; Virginia, O.-V.R.; Feregrino-Perez, A.A.; Hernandez, A.C.; Gerardo, G.-G.R. Integrating Plant Nutrients and Elicitors for Production of Secondary Metabolites, Sustainable Crop Production and Human Health: A Review. Int. J. Agric. Biol. 2017, 19, 391-402. [CrossRef]

14. Amdoun, R.; Khelifi, L.; Khelifi-Slaoui, M.; Amroune, S.; Benyoussef, E.-H.; Thi, D.V.; Assaf-Ducrocq, C.; Gontier, E. Influence of Minerals and Elicitation on Datura stramonium L. Tropane Alkaloid Production: Modelization of the In Vitro Biochemical Response. Plant Sci. 2009, 177, 81-87. [CrossRef]

15. Akhgari, A.; Laakso, I.; Maaheimo, H.; Choi, Y.H.; Seppänen-Laakso, T.; Oksman-Caldentey, K.-M.; Rischer, H. Methyljasmonate Elicitation Increases Terpenoid Indole Alkaloid Accumulation in Rhazya Stricta Hairy Root Cultures. Plants 2019, 8, 534. [CrossRef] [PubMed]

16. Taha, A.J.; Twaij, B.M.A. Effect of Some Chemical and Physical Elicitors on Some Secondary Compound Induction of Ricinus communis through Callus Induction. Al-Mustansiriyah J. Sci. 2017, 28, 25-34.

17. Mady, M. Effect of Foliar Application with Salicylic Acid and Vitamin E on Growth and Productivity of Tomato (Lycopersicon Esculentum, Mill.) Plant. J. Plant Prod. 2009, 34, 6715-6726. [CrossRef]

18. Xu, Y.W.; Wen Xu, Y. Effects of Salicylic Acid on Monoterpene Production and Antioxidant Systems in Houttuynia cordata. Afr. J. Biotechnol. 2012, 11, 1364-1372.

19. Singh, P.K.; Gautam, S. Role of Salicylic Acid on Physiological and Biochemical Mechanism of Salinity Stress Tolerance in Plants. Acta Physiol. Plant. 2013, 35, 2345-2353. [CrossRef]

20. Gai, Q.-Y.; Jiao, J.; Wang, X.; Zang, Y.-P.; Niu, L.-L.; Fu, Y.-J. Correction to: Elicitation of Isatis tinctoria L. Hairy Root Cultures by Salicylic Acid and Methyl Jasmonate for the Enhanced Production of Pharmacologically Active Alkaloids and Flavonoids. Plant Cell Tissue Organ Cult. 2019, 137, 417. [CrossRef]

21. Hadizadeh, M.; Ofoghi, H.; Kianirad, M.; Amidi, Z. Elicitation of Pharmaceutical Alkaloids Biosynthesis by Salicylic Acid in Marine Microalgae Arthrospira Platensis. Algal Res. 2019, 42, 101597. [CrossRef] 
22. Rodriguez-Salus, M.; Bektas, Y.; Schroeder, M.; Knoth, C.; Vu, T.; Roberts, P.; Kaloshian, I.; Eulgem, T. The Synthetic Elicitor 2-(5-Bromo-2-Hydroxy-Phenyl)-Thiazolidine-4-Carboxylic Acid Links Plant Immunity to Hormesis. Plant Physiol. 2016, 170, 444-458. [CrossRef]

23. Hasanuzzaman, M.; Matin, M.A.; Fardus, J.; Hasanuzzaman, M.; Hossain, M.S.; Parvin, K. Foliar application of salicylic acid improves growth and yield attributes by upregulating the antioxidant defense system in Brassica campestris plants grown in lead-amended soils. Acta Agrobot. 2019, 72, 1765. [CrossRef]

24. Zamaninejad, M.; Khorasani, S.K.; Moeini, M.J.; Heidarian, A.R. Effect of salicylic acid on morphological characteristics, yield and yield components of corn (Zea mays L.) under drought condition. Eur. J. Exp. Biol. 2013, 3, 153-161.

25. Tucuch-Haas, C.; Alcántar-González, G.; Trejo-Téllez, L.I.; Volke-Haller, H.; Salinas-Moreno, Y.; Larqué-Saavedra, A. Effect of salicylic acid on growth, nutritional status, and performance of maize (Zea mays). Agrociencia 2017, 51, 771-781.

26. Estaji, A.; Niknam, F. Foliar salicylic acid spraying effect on growth, seed oil content, and physiology of drought-stressed Silybum marianum L. plant. Agric. Water Manag. 2020, 234, 106116. [CrossRef]

27. Safeer, M.; Rafi, Q.; Altaf, M.M.; Naeem, S.; Omer, F.; Iqbal, M.M.; Shakeel, A. Exogenous application of salicylic acid ameliorates growth and yield of sunflower (Helianthus annuus L.) in saline soil. Agrociencia 2019, 53, 207-217.

28. Ullah, F.; Bano, A. Effect of plant growth regulators on oil yield and biodiesel production of safflower (Carthamus tinctorius L.). Braz. J. Plant Physiol. 2011, 23, 27-31. [CrossRef]

29. Flores-Macías, A.; Vela-Correa, G.; Rodríguez-Gamiño, M.; Akhtar, Y.; Figueroa-Brito, R.; Pérez-Moreno, V.; Ramos-López, M.A. Effect of potassium nitrate on the production of ricinine by Ricinus communis and its insecticidal activity against Spodoptera frugiperda. Rev. Fitotec. Mex. 2016, 39, 41-47.

30. Wang, Z.; Li, D.; Zhou, Z.; Li, B.; Yang, W. A simple method for screening and quantification of ricinine in feed with HPLC and LC-MS. J. Chromatogr. Sci. 2009, 47, 585-588. [CrossRef]

31. Isenberg, S.L.; Carter, M.D.; Miller, M.A.; Noras, A.I.; Mojica, M.A.; Carlsen, S.T.; Bulathsinghala, C.P.; Thomas, J.D.; Johnson, R.C. Quantification of ricinine and abrine in human plasma by HPLC-MS-MS: Biomarkers of exposure to ricin and abrin. J. Anal. Toxicol. 2018, 42, 630-636. [CrossRef]

32. Nebo, L.; Varela, R.M.; Fernandes, J.B.; Palma, M. Microwave-Assisted Extraction of Ricinine from Ricinus communis Leaves. Antioxidants 2019, 8, 438. [CrossRef]

33. Wamaket, N.; Dieng, H.; Komalamisra, N.; Apiwathnasorn, C.; Morales, R.E.; Thanomsub, B.W.; Srisawat, R.; Attrapadung, S. Larvicidal and Adulticidal Activities of Castor Oil against the Dengue Vector, Aedes aegypti. Trop. Biomed. 2018, 35, 610-618.

34. Vasco-Leal, J.F.; Cuellar-Nuñez, M.L.; Luzardo-Ocampo, I.; Ventura-Ramos, E.; Loarca-Piña, G.; Rodriguez-García, M.E. Valorization of Mexican Ricinus communis L. Leaves as a Source of Minerals and Antioxidant Compounds. Waste Biomass Valorization 2021, 12, 2071-2088. [CrossRef]

35. Ghassemi-Golezani, K.; Hassanzadeh, N.; Shakiba, M.-R.; Esmaeilpour, B. Exogenous Salicylic Acid and 24-Epi-Brassinolide Improve Antioxidant Capacity and Secondary Metabolites of Brassica nigra. Biocatal. Agric. Biotechnol. 2020, 26, 101636. [CrossRef]

36. Henao, G.J.P.; Pajón, C.M.G.; Torres, J.M.C. Actividad insecticida de extractos vegetales sobre Aedes aegypti (Diptera: Culicidae) vector del dengue en Colombia. CES Med. 2007, 21, 47-54.

37. Duarte, J.L.; de Faria Motta Oliveira, A.E.M.; Pinto, M.C.; Chorilli, M. Botanical Insecticide-based Nanosystems for the Control of Aedes (Stegomyia) Aegypti Larvae. Environ. Sci. Pollut. Res. 2020, 27, 28737-28748. [CrossRef]

38. Gafner, S.; Bergeron, C. The Challenges of Chemical Stability Testing of Herbal Extracts in Finished Products Using State-of-the-Art Analytical Methodologies. Curr. Pharm. Anal. 2005, 1, 203-215. [CrossRef]

39. Hilbig, J.; Alves, V.R.; Müller, C.M.O.; Micke, G.A.; Vitali, L.; Pedrosa, R.C.; Block, J.M. Ultrasonic-Assisted Extraction Combined with Sample Preparation and Analysis Using LC-ESI-MS/MS Allowed the Identification of 24 New Phenolic Compounds in Pecan Nut Shell [Carya illinoinensis (Wangenh) C. Koch] Extracts. Food Res. Int. 2018, 106, 549-557. [CrossRef] [PubMed]

40. Valencia-Botin, A.J.; Gutiérrez-Lomelí, M.; Morales-Del-Río, J.A.; Guerrero-Medina, P.J.; Robles-García, M.A.; Ruiz-Cruz, S.; Wong-Corral, F.J;; Borboa-Flores, J.; Rueda-Puente, E.O.; Del-Toro-Sánchez, C.L. Efecto Inhibitorio de Extractos de Vitex mollis Kunth Contra Bacterias y Especies de Fusarium de Importancia Humana y Agrícola. Rev. Fitotec. Mex. 2018, 41, 353-363.

41. Bullangpoti, V.; Khumrungsee, N.; Pluempanupat, W.; Kainoh, Y.; Saguanpong, U. Toxicity of Ethyl Acetate Extract and Ricinine from Jatropha gossypifolia Senescent Leaves against Spodoptera exigua Hübner (Lepidoptera: Noctuidae). J. Pestic. Sci. 2011, 36, 260-263. [CrossRef]

42. Melo, W.C.; dos Santos, A.S.; Santa Anna, L.M.; Pereira, N., Jr. Acid and Enzymatic Hydrolysis of the Residue from Castor Bean (Ricinus communis L.) Oil Extraction for Ethanol Production: Detoxification and Biodiesel Process Integration. J. Braz. Chem. Soc. 2008, 19, 418-425. [CrossRef]

43. Hernández Martínez, M.; Montes Hernández, S. Guanajuatoil variedad de higuerilla para la extracción de aceite industrial para Guanajuato. Folleto Técnico Núm. X INIFAP-CIRCE Campo Experimental Bajío. 2018. Available online: https://es.scribd. com/document/447504555/4774-Produccion-de-semilla-de-higuerilla-Ricinus-communis-L-en-Guanajuato (accessed on 20 May 2021).

44. Barrios-Gómez, E.J.; Canul-Ku, J.; Hernández-Arenas, M.G.; Solís-Bonilla, J.L. Evaluation of two castor bean cycles in Morelos, Mexico: Sowing and regrowth. Rev. Mex. Cienc. Agríc. 2018, 9, 1663-1673. 